\title{
Neocordana gen. nov., the causal organism of Cordana leaf spot on banana
}

\author{
MARGARITA HERNÁNDEZ-RESTREPO ${ }^{1,2}$, \\ JOHANNES Z. GROENEWALD ${ }^{1}$, \\ PEDRO W. CROUS ${ }^{1,2,3,4}$
}

${ }^{l}$ CBS-KNAW Fungal Biodiversity Centre, Uppsalalaan 8, 3584 CT Utrecht, The Netherlands.

${ }^{2}$ Department of Microbiology and Plant Pathology, Forestry and Agricultural Biotechnology Institute (FABI), University of Pretoria, Pretoria 0002, South Africa

${ }^{3}$ Microbiology, Department of Biology, Utrecht University, Padualaan 8, 3584 CH Utrecht, The Netherlands

${ }^{4}$ Wageningen University and Research Centre (WUR), Laboratory of Phytopathology, Droevendaalsesteeg 1, 6708

PB Wageningen, The Netherlands

Corresponding author: Margarita Hernández-Restrepo

E-mail: m.hernandez@cbs.knaw.nl

\begin{abstract}
Cordana leaf spot of banana is shown to be associated with several species of a new genus described here as Neocordana gen. nov. Furthermore, Neocordana belongs to Pyriculariaceae (Magnaporthales) rather than Cordanaceae where the type species of Cordana, C. pauciseptata resides. Neocordana is established to accommodate Cordana musae, C. johnstonii, C. versicolor, and a previously undescribed species, N. musicola, which is morphologically and phylogenetically distinct. Neocordana species are found to be associated with leaves of Musa spp. (Musaceae) and Canna denudata (Cannaceae). Based on these results, Cordanaceae is best recognized in a separate order, established here as Cordanales ord. nov.
\end{abstract}

Key Words: Cordanales, Magnaporthales, Musa, plant pathogenic fungi, Pyriculariaceae, systematics. 


\section{Introduction}

Cordana leaf spot is a common and widespread disease on banana and plantain. Although it is considered as a minor pathogen of banana, it can cause serious defoliation of plantains in Central America during and following periods of wet weather (Jones 1999, Ploetz et al. 2003). Cordana leaf spot is characterised by large, pale brown, oval to fusiform necrotic lesions with pale grey concentric rings, with a dark brown border surrounded by a bright yellow halo, separating lesions from healthy leaf tissue (Jones 1999). Most damage occurs when the pathogen gains entry to leaf tissue weakened because of age, adverse environmental conditions, nutritional deficiencies, wounds or through lesions caused by other pathogens. The leaves ultimately turn brown and dry out (Jones 1999). This is especially apparent when the disease occurs together with Sigatoka leaf spots (Arzanlou et al. 2008), in which case the lesions may encompass the entire leaf margin and large portions of the lamina can be affected (Ploetz et al. 2003). Leaf infection normally occurs at night during rainy periods or when dew is present. The conidia germinate in a film of moisture on the leaf surface and after a few hours appressoria are formed. The appressoria enable the fungus to penetrate into the host epidermal cells. Species most commonly associated with Cordana leaf spot of banana include Cordana musae (Zimm.) Höhn. (1923: 60) and C. johnstonii M.B. Ellis (1971: 125). Cordana leaf spot has been reported mainly on M. sapientum L. but also can be found on M. acuminata ssp. banksii N.W.Simmonds, $M$. acuminata ssp. banksii $\times$ M. schizozarpa N.W.Simmonds, M. balbisiana Colla, M. boman Argent, M. maclayi F.Muell., M. schizozarpa N.W.Simmonds and Enset glaucum (Roxb.) Cheesman (Jones, 1999). Another plant pathogenic species, Cordana versicolor D.J. Soares \& R.W. Barreto (2005: 18), was described from Brazil causing eye-spot disease on leaves of Canna denudata (Soares et al. 2005).

The asexual genus Cordana was erected by Preuss (1851) with C. pauciseptata Preuss (1851: 129) as type species. Species of Cordana are characterized by brown, septate conidiophores with swollen conidiogenous zones, terminal and intercalary conidiogenous cells, and pale brown to brown, 0-1-septate conidia. Ecologically, Cordana species can be separated into two groups, namely phanerogam leaf-inhabiting species (saprobic or pathogenic) or saprobic on rotten wood or in soil (de Hoog et al. 1983). Saprobic species as C. abramovii Seman \& Davydkina (1983: 20), C. bisby (Timonin) M. Hern.-Rest., Gené \& Guarro (2014: 106), C. ellipsoidea de Hoog (1973: 22), C. inaequalis S. Hughes (1983: 246), C. mercadiana M. Hern.- 
Restr, J. Mena, Gene \& Guarro (2014: 106), C. solitaria V. Rao \& de Hoog (1986: 28), C. terrestris (Timonin) M. Hern.-Rest., Gené \& Guarro (2014: 106), and C. verruculosa M. Hern.Restr, J. Mena, Gene \& Guarro (2014: 106), including the type species, C. pauciseptata, cluster in Cordanaceae Nann. (1934: 498) (Order incertae sedis), in the Sordariomycetes (HernándezRestrepo et al. 2014, Zelski et al. 2014). Nevertheless, plant pathogenic species such as $C$. musae, C. johnstonii, and C. versicolor cluster apart, and are phylogenetically unresolved.

The aims of this work were to designate a suitable neotype specimen for C. musae with a living culture and resolve its phylogeny, and to describe a new genus to accommodate $C$. musae and related species.

\section{Materials and methods}

\section{Isolates}

Fungal isolates used in this study were obtained from culture collection of Pedro Crous (CPC) housed at the CBS-KNAW Fungal Biodiversity Centre (CBS) Utrecht, The Netherlands, and from the CBS culture collection. Isolates were cultured on malt extract agar (MEA), oatmeal agar (OA) and synthetic nutrient deficient agar (SNA) (recipes in Crous et al., 2009b), plus sterilized Musa leaves, and incubated at $25{ }^{\circ} \mathrm{C}$ under daylight conditions. Reference strains were deposited in CBS, nomenclature and taxonomic information in MycoBank (www.mycobank.org) (Crous et al. 2004).

\section{Morphology}

Slide preparations were prepared by mounting fungal material in clear lactic acid from sporulating colonies. Observations and photomicrographs were made with a Nikon SMZ1500 stereo-microscope, and with a Nikon eclipse Ni compound microscope, using a Nikon DS-U3 digital camera (Nikon, Tokyo, Japan) and NIS elements imaging software. Colony characters and pigment production were noted after 1 week of growth on MEA and OA incubated at $25{ }^{\circ} \mathrm{C}$. Colony colours (surface and reverse) were treated according to the colour chart of Rayner (1970). 


\section{DNA isolation, amplification and analyses}

Genomic DNA was extracted from fungal colonies growing on MEA using the UltraCleanTM Microbial DNA Isolation kit (MoBio Laboratories, Inc., Solana Beach, CA, USA) and Wizard® Genomic DNA purification kit (Promega, Madison, USA), according to the manufacturer's protocols. The primers V9G (de Hoog \& Gerrits van den Ende 1998) and LR5 (Vilgalys \& Hester 1990) were used to amplify part (ITS) of the nuclear rDNA operon spanning the 3' end of the 18S rRNA gene, the first internal transcribed spacer (ITS1), the 5.8S rRNA gene, the second ITS region (ITS2) and approximately $900 \mathrm{bp}$ of the 5 ' end of the 28S rRNA gene. The primers ITS4 (White et al. 1990) and LSU1Fd (Crous et al. 2009a) were used as internal sequence primers to ensure good quality sequences over the entire length of the amplicon. The program SeqMan Pro (DNASTAR, Madison, WI, USA) was used to obtain consensus sequences of each isolate. Megablast searches using ITS and LSU sequences were performed in NCBI's GenBank nucleotide sequence database to identify the closest matching sequences, which are added to the sequences alignment. Sequences were aligned with MAFFT v. 7 (Katoh \& Standley 2013) using the default settings and adjusted by hand in MEGA v. 6.06 (Tamura et al. 2013). To address the phylogenetic relationships among taxa, Bayesian inference (BI) and Maximum Likelihood (ML) were used. MrModel test v. 2.2 (Nylander 2004) was used to determine the best nucleotide substitution model settings prior to the Bayesian analysis in MrBayes v. 3.2.1 (Ronquist et al. 2012). ML analysis was performed with RAxML v. 7.0.4 (Stamakis et al. 2008). Nodal support was assessed by $>0.95$ Posterior probabilities for the Bayesian analysis (PP) determined by calculating 50\% majority rule consensus tree from the remaining 2706 trees, and from $>70 \%$ maximum likelihood bootstrap values (MLB).

Sequences derived in this study were deposited at GenBank, the alignments and trees in TreeBASE (www.treebase.org/treebase/index.html). The phylogenetic trees were edited using Tree View 1.4.0 and Adobe Illustrator CS5.1.

\section{Results}

\section{Phylogeny}

Amplicons of approximately $1000 \mathrm{bp}$ were obtained of the partial LSU gene and $550 \mathrm{bp}$ of the ITS region. The LSU alignment was used to resolve the generic placement of the strains and the ITS to determine species identification. 


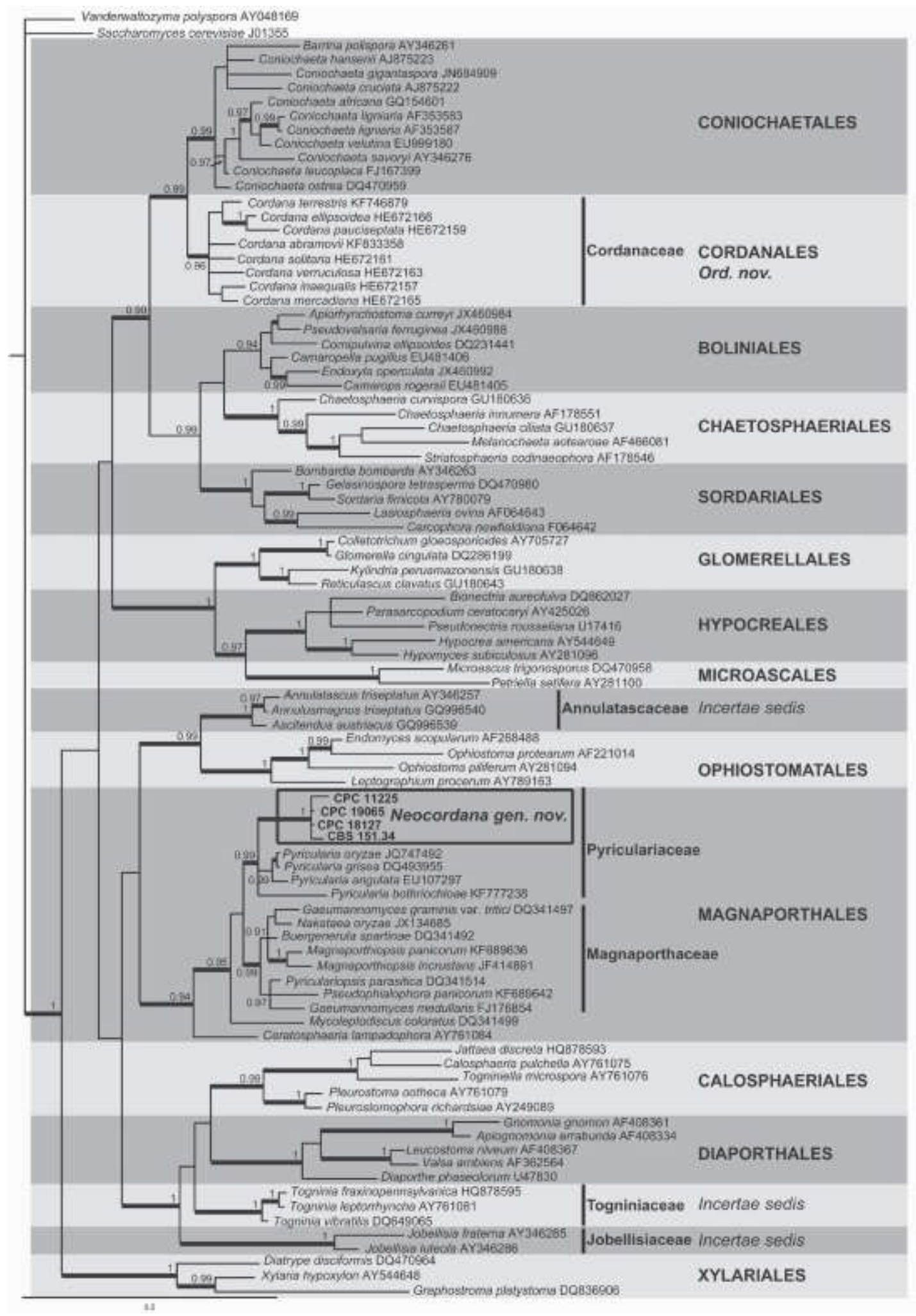

Figure 1. Phylogenetic analyses based on LSU rDNA sequences. Bayesian posterior probabilities above 0.95 are shown at the nodes. Thickened lines indicate a Maximum Likelihood bootstrap supports above $70 \%$. The tree was rooted with Saccharomyces cerevisiae J01355 and Vanderwaltozyma polyspora AY048169. 


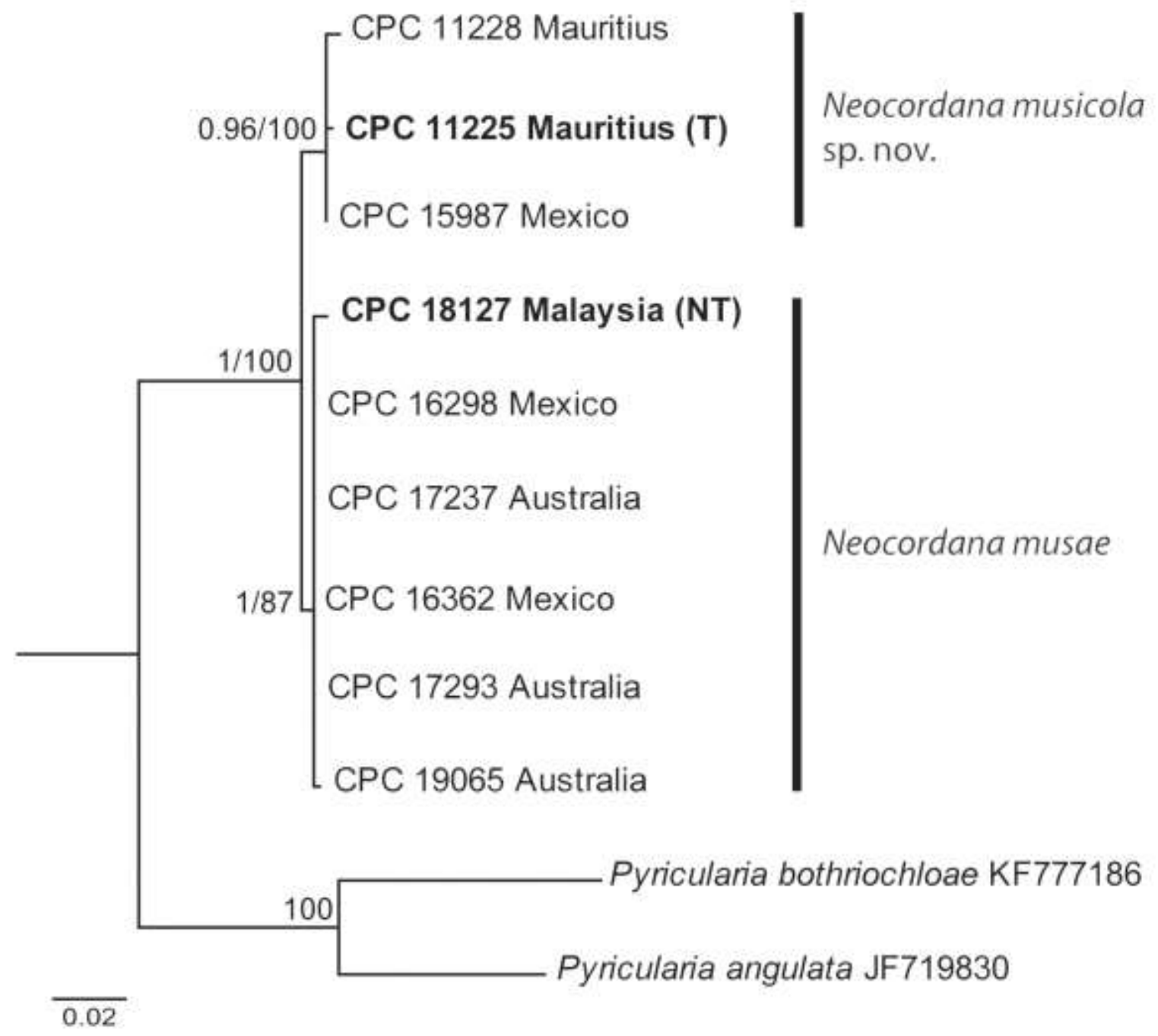

Figure 2. Maximum likelihood (RAxML) phylogenetic tree based on ITS sequences of Neocordana isolates. Bayesian posterior probability values and Bootstrap support values are shown at the nodes. The tree was rooted with Pyricularia bothriochloae KF777186 and Pyricularia angulata JF719830. Ex-type isolates are indicated in bold.

The LSU alignment contained 84 sequences, including two outgroups (Saccharomyces cerevisiae J01355 and Vanderwaltozyma polyspora AY048169), and 1021 characters including alignment gaps were used in the phylogenetic analysis. Dirichlet base frequencies and the $\mathrm{GTR}+\mathrm{I}+\mathrm{G}$ model with inverse gamma-distributed were used as substitution model. In Bayesian analysis 50\% consensus trees and posterior probabilities were calculated from the 5412 tree left after discarding 2706 trees (the first $25 \%$ of generations) for burn-in (Figure 1).

The main topology is maintained in the ML tree based on LSU sequences. Clades corresponding with families and orders in Sordariomycetes were well-supported 
(Annulastascaceae, Boliniales, Chaetosphaeriales, Coniochaetales, Cordanaceae, Diaporthales, Glomerellales, Hypocreales, Magnaporthales, Microascales, Ophiostomatales, Sordariales, and Xylariales). Isolates of Cordana musae appeared as a distinct lineage among the Pyriculariaceae in Magnaporthales, rather than Cordanaceae, where the type species C. pauciseptata is placed. These results indicated that the genus Cordana is polyphyletic. A new genus and new combinations are therefore required to accommodate Cordana musae and related phytopathogenic species.

The ITS alignment contained 11 sequences (including two outgroups, Pyricularia bothriochloae KF777186 and Pyricularia angulata JF719830), and 521 characters including alignments gaps were used in the phylogenetic analysis. The ITS phylogenetic tree (Figure 2) resolved two different clades representing isolates from Musa spp. collected in different countries.

\section{Taxonomy}

Cordanales M. Hern.-Rest. \& Crous, ord. nov.

MycoBank MB811104

Ascomata superficial or slightly immersed, solitary or gregarious in scattered groups, globose to broadly ovoid, papillate, basal stroma sometimes present, smooth, black to dark brown, periphysate. Asci cylindrical, short-stalked, unitunicate, with 8 uniseriate ascospores. Paraphyses hyaline, simple, septate. Ascospores ellipsoid to fusiform, 1-septate, pale brown or hyaline becoming brown. Conidiophores erect, simple or branched, brown, with a few rhizoidal hyphae arising from the base. Conidiogenous cells polyblastic, denticulate. Conidia 0-1-septate, pale to dark brown, smooth or verruculose.

Type:-Cordana pauciseptata Preuss

Family included:-Cordanaceae Nann.

Note:-The Cordanaceae was established for the genus Cordana. Based on the ascomatal morphology that is porosphaerella-like, Cordana has been allied with the Trichosphaeriaceae 
and Chaetosphaeriaceae (Müller \& Samuels 1982, Réblová et al. 1999). Recent molecular studies reported the family to be phylogenetically closely related to the Coniochaetales (Réblová \& Winka 2000, Huhndorf et al. 2004, Réblová \& Seifert 2007, Hernández-Restrepo et al. 2014, Zelski et al. 2014). Coniochaetales includes only one family Coniochaetaceae, with members characterized by ascomata lacking of stromatic tissue, ascospores with elongated germ slits and phialidic asexual morphs (Huhndorf et al. 2004), clearly different from members of Cordanaceae that can have a basal stroma, ascospores without germ slits and polyblastic asexual morphs. Our data strongly support the Cordanaceae as being monophyletic and a new order, Cordanales, is established for the Cordanaceae.

Neocordana M. Hern.-Rest. \& Crous, gen. nov.

MycoBank MB811105

Etymology: Neo- new, Cordana- asexual genus, in reference to their similarity with the genus Cordana.

Colonies effuse, grey to brown, hairy. Mycelium superficial and immersed, on the agar and on the plant cuticle, hyphae, smooth, septate, hyaline becoming brown with age. Conidiophores differentiated, erect, straight to flexuous, brown at the base becoming paler toward the apex, smooth, swollen basal cell beneath the host epidermis. Conidiogenous cells holoblastic, sympodial, denticulate, cylindrical to obclavate, terminal and intercalary, smooth, pale brown to brown. Conidia dry, solitary, pale brown, 1-sepate, broadly ellipsoidal, oblong, obovoid, obclavate to pyriform, smooth, thick-walled, with a visible darker, thickened hilum. Appressoria present.

Type species:-Neocordana musae (Zimm.) M. Hern.-Rest. \& Crous Sexual morph: Unknown.

Neocordana johnstonii (M.B. Ellis) M. Hern.-Rest. \& Crous, comb. nov. MycoBank MB811113

Basionym: Cordana johnstonii M.B. Ellis, Mycol. Pap. 125: 8 (1971)

Descriptions and illustrations:-Ellis (1971), Priest (1990). 


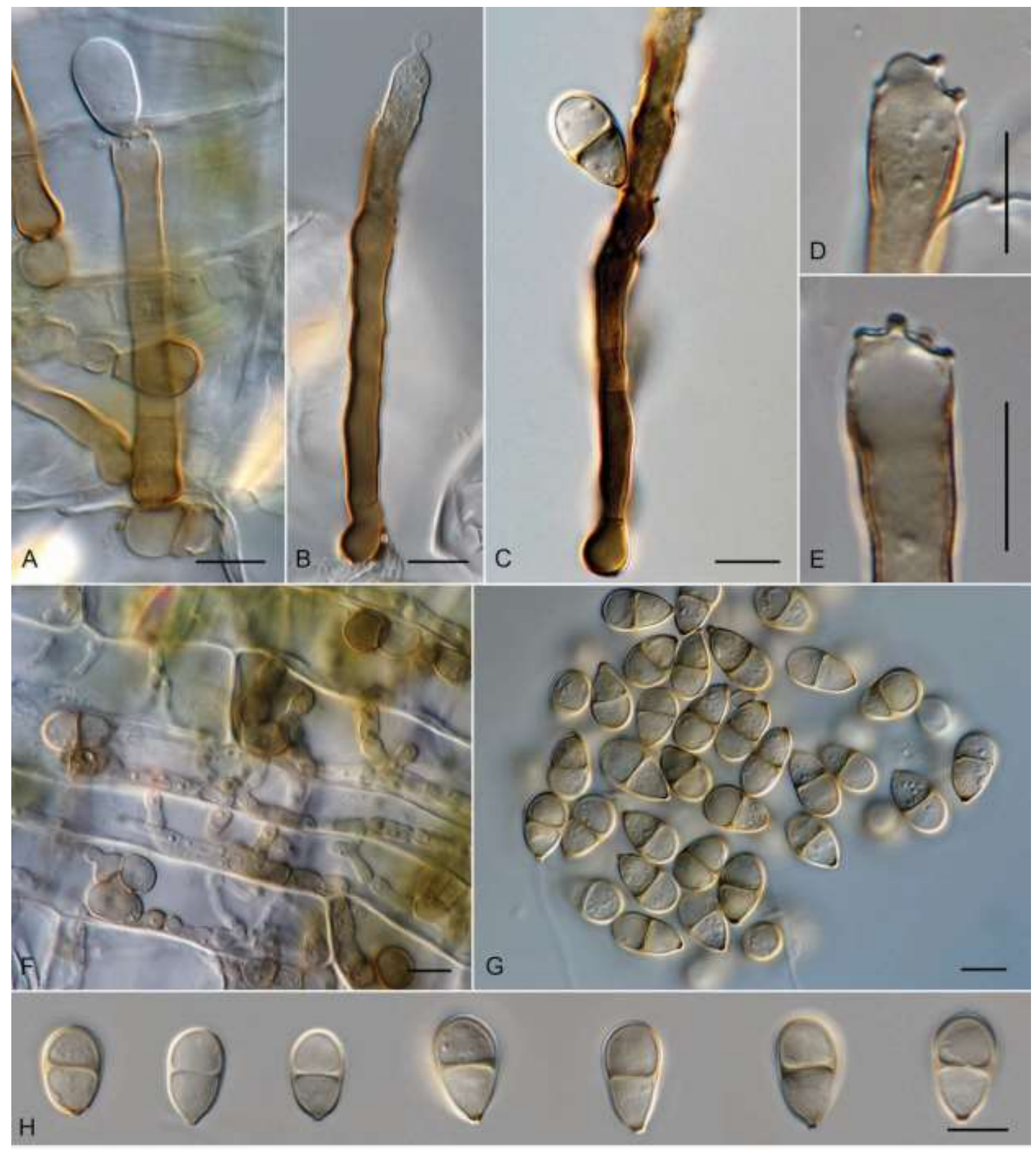

Figure 3. Neocordana musae (CPC 18127, ex-neotype culture) on Musa leaves on SNA. A-B. Conidiophores. D-E. Conidiogenous cells. f. Intracellular hyphae. G-I. Conidia. Scale bars A-E $=10 \mu \mathrm{m}$. 
Type:-INDONESIA. West Irian, Enarotali, 17 May 1960, on leaves of Musa sapientum, D. Shaw \& A. Johnston, (holotype IMI 81492).

Distribution:-AUSTRALIA. Queensland (Tallebudgera, Mudgeeraba, Currumbin, South coast of Queensland), New South Wales, Norfolk Island, Lord Howe Island. INDONESIA. West Irian. MALAYSIA. Cameron Highlands. PHILIPPINES. Malaya. TONGA.

Neocordana musae (Zimm.) M. Hern.-Rest. \& Crous, comb. nov.

MycoBank MB811106, Figure 3.

Basionym: Scolecotrichum musae Zimm., Zentbl. Bakt. ParasitKde, Abt. II 8: 220 (1902) (as Scolicotrichum)

= Cordana musae (Zimm.) Höhn., Zentbl. Bakt. ParasitKde, Abt. II 60: 7 (1923)

Mycelium superficial and immersed, hyphae smooth, hyaline to brown; intracellular hyphae smooth, hyaline to brown. Conidiophores brown, smooth, 46-118.5 × 5-6.5 $\mu \mathrm{m}$. Conidiogenous cells terminal and intercalary, 15-72.5 $\times 5-9 \mu \mathrm{m}$, denticulate; denticles up to $2 \mu \mathrm{m}$ long, $0.5-1.5$ $\mu \mathrm{m}$ wide. Conidia obclavate, pyriform, mostly obovoid, $14.5-19 \times 8-11.5 \mu \mathrm{m}, 1-$ septate, thickwall, pale brown, base darker, flat, $1-1.5 \mu$ m wide.

Culture characteristics:-Colonies on MEA after 1 week attaining $25 \mathrm{~mm}$ diam, elevated, cottony, aerial mycelium white with mouse grey zones (sporulation), exudate hyaline to pale luteous, margin diffuse; reverse black in the centre, with concentric rings isabelline to umber or luteous to ochreous. On OA colonies very similar to that observed on MEA.

Type:-INDONESIA. Java, Buitenzorg, 1920, on Musa sapientum, Zimmermann A., Centralbl. F. Bakt Abt. II. Bd. 8. S220 (holotype not found and presumed missing). MALAYSIA. 1 April 2011, on Musa sp., Mee Hua Wong (neotype designated here CBS H22054!, ex-neotype strain CPC 18127 = CBS 139318).

Additional cultures examined:-AUSTRALIA. Queensland, 21 January 2011, on Musa sp., unknown collector, CBS $139319=$ CPC 19065. MEXICO. Tabasco, Villa Hermosa, 16 
December 2008, on Musa sp., Maria de J. Yarez Morales, CPC 16362; Tapechula, Chiapas, 16 December 2008, on Musa sp., Maria de J. Yarez Morales, CPC 16298. UNKNOWN COUNTRY, February 1934, on Musa sapientum, G. Stahel, CBS 151.34.

Distribution:-Widespread in the tropics with the host.

Notes:-In the ITS phylogenetic tree (Figure 2) Neocordana musae is represented by six isolates from Musa leaves collected from different countries, namely Australia, Malaysia and Mexico. Originally N. musae was described from Java (Zimmermann 1902), but the type material is presumably lost. Among the isolates studied here, we chose isolate CPC 18127 as exneotype because Malaysia is closest to the location where this fungus was collected for the first time; furthermore this isolate is morphologically similar to the fungus described and illustrated by Zimmermann (1902), and occurs commonly on Musa spp. in tropical regions.

Neocordana musicola M. Hern.-Rest. \& Crous, sp. nov.

MycoBank MB811107, Figure 4.

Etymology: Named after the host from which it was isolated, Musa.

Diagnosis: Conidiophores up to $125 \times 4-5.4 \mu \mathrm{m}$, conidiogenous cells $15-37.6 \times 4.2-56$ $\mu \mathrm{m}$, conidia oblong to obovoid, 1-septate, $14.5-20 \times 6.5-9.5 \mu \mathrm{m}$, base $0.9-1.2 \mu \mathrm{m}$ diam.

Mycelium superficial and immersed, hyphae smooth, hyaline to brown; intracellular hyphae hyaline to brown. Conidiophores brown, smooth, 35-125 $\times 4-5.4 \mu \mathrm{m}$. Conidiogenous cells polyblastic, terminal and intercalary, 15-37.6 $\times 4.2-56 \mu \mathrm{m}$, denticulate; denticles up to $1.5 \mu \mathrm{m}$ long, 0.6-1 $\mu \mathrm{m}$ wide. Conidia oblong to obovoid, 14.5-20 × 6.5-9.5 $\mu \mathrm{m}, 1$-septate, thickwalled, pale brown, base darker, flat, $0.9-1.2 \mu \mathrm{m}$ wide.

Culture characteristics:-Colonies on MEA after 1 week attaining $20 \mathrm{~mm}$, cottony, aerial mycelium white, mouse grey towards the edge (sporulation), and margin diffuse; reverse fuscous black in the centre, luteous at the edge. On OA colonies very similar to that observed in MEA. 


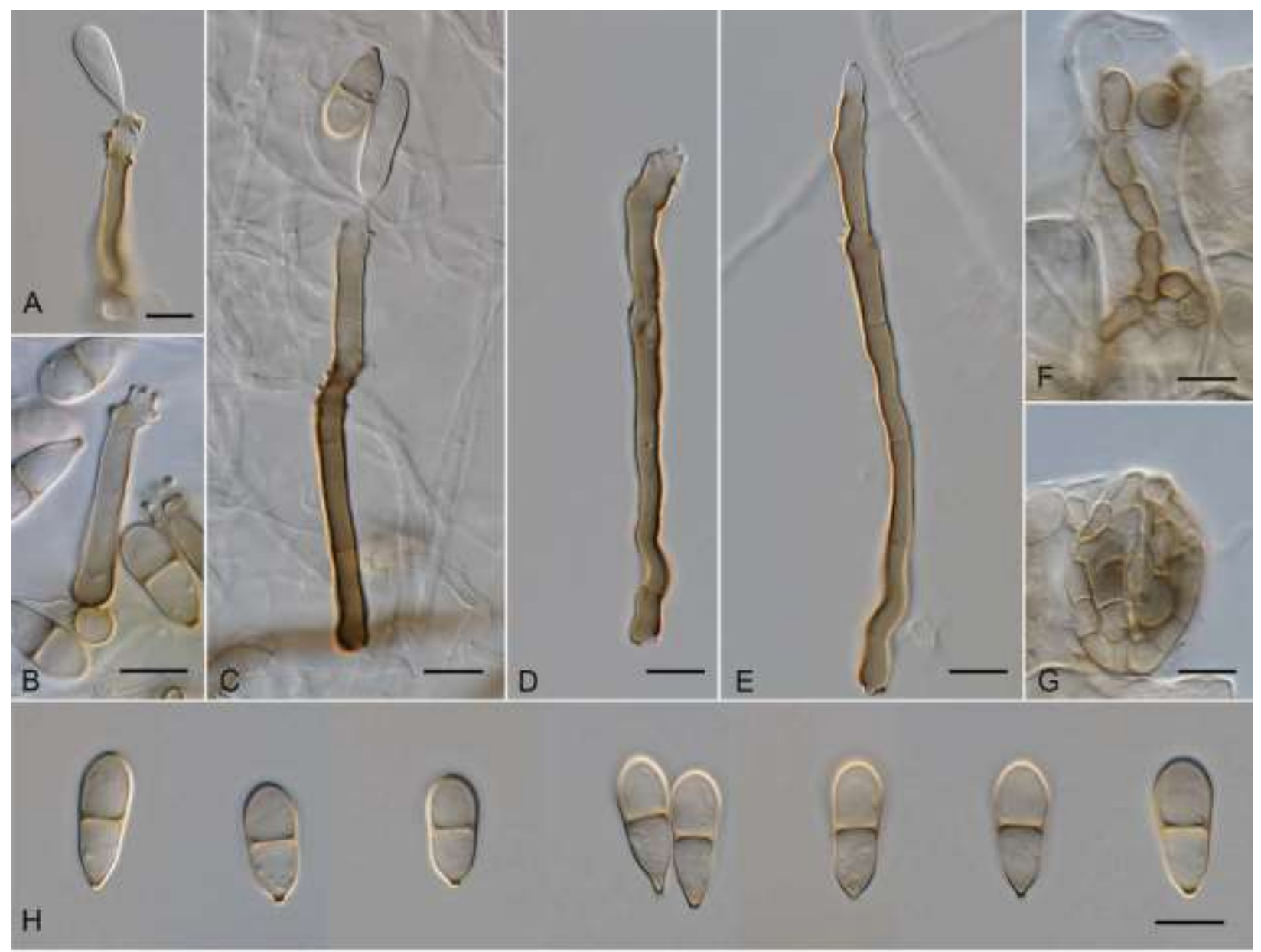

Figure 4. Neocordana musicola (CPC 11225, ex-type culture) on Musa leaves on SNA. A-E. F-G. Intracellular hyphae. H. Conidia. Scale bar A-H = $10 \mu \mathrm{m}$.

Type:-MAURITIUS. 15 June 2004, on Musa sp., Yasmina Jaufeerally-Fakim, (holotype CBS H-22055!, culture ex-type CBS 139316 = CPC 11225 = S 1024).

Additional cultures examined:-MAURITIUS. 15 June 2004, on Musa sp., Yasmina Jaufeerally-Fakim, CPC 11228. MEXICO. Tecoman, Colima, INIFAB, 30 October 2008, on Musa sp., Maria de J. Yarez Morales, CPC 15987 = CBS 139317.

Distribution:-MAURITIUS and MEXICO.

Notes:-Neocordana musicola is represented by three strains, two of them collected from Mauritius and the third from Mexico. $N$. musicola can be differentiated from the other species in 
the genus by their narrower obovoid to oblong conidia. $N$. musae has obovoid to pyriform conidia, 11-20 × 8-11.5 $\mu \mathrm{m}$, while those of $N$. johnstonii are broadly ellipsoidal, 20-30 × 12-18 $\mu \mathrm{m}$, and conidia of $N$. versicolor (see below) are 15-25 × 10-15 $\mu \mathrm{m}$. Molecular data based on the ITS sequences show $2.5 \%$ differences between N. musae (CPC 18127) and N. musicola sp. nov. (CPC 11225).

Neocordana versicolor (D.J. Soares \& R.W. Barreto) M. Hern.-Restr. \& Crous, comb. nov.

MycoBank MB811114

Basionym: Cordana versicolor D.J. Soares \& R.W. Barreto, Fungal Diver. 18: 148 (2005)

Description and illustration: Soares et al. (2005).

Type:-BRAZIL. Minas Gerais, Viçosa, Associacao Atletica Banco do Brasil, 02 May 1999, on living leaves of Canna denudata, R.W. Barreto (holotype VIC 22157).

\section{Distribution:-BRAZIL.}

\section{Discussion}

For many years the causal agents of a distinctive leaf spot disease on banana were considered as members of the genus Cordana (von Höhnel 1923, Ellis 1971, Priest 1990, Jones 1999). The disease was initially attributed to a pathogen described as Scolecotrichum musae on Musa sapientum from Java (Indonesia) by Zimmermann (1902), and later transferred to Cordana by von Höhnel (1923). Ellis (1971) subsequently introduced a second species isolated on Musa sapientum from West Irian (Indonesia) as C. johnstonii, which causes a disease very similar in appearance to the one caused by $C$. musae. Morphologically these species can be differentiated based on conidial size and shape. Conidia of $C$. musae are obclavate to pyriform, 14-18 $\times 8-10$ $\mu \mathrm{m}$, while those of $C$. johnstonii are broadly ellipsoidal to subglobose, larger and wider, 19-26 $\times$ 14-16 $\mu \mathrm{m}$. Priest (1990) reported that leaf spots caused by C. johnstonii are generally smaller (3 $\times 1 \mathrm{~cm})$ and become fusiform with age, in contrast to the larger $(7 \times 2 \mathrm{~cm})$, oval to elliptical spots caused by C. musae. 
In our phylogenetic tree based on LSU sequences (Figure 1), cordana-like strains isolated from symptomatic leaves of Musa from different countries constituted a distant clade in Pyriculariaceae (Magnaporthales). Recently phylogenetic studies (Hernández-Restrepo et al. 2014) demonstrated that members of Cordana occupy a monophyletic clade in the family Cordanaceae, as the sister clade of Coniochaetales in Sordariomycetes. Cordanales is here erected for the single family Cordanaceae. On the other hand, Neocordana is introduced to accommodate phytopathogenic species similar to Cordana but closely related to Pyriculariaceae (Magnaporthales) rather than Cordanaceae. The family Pyriculariaceae was recently introduced by Klaubauf et al. (2014) and includes important plant pathogens along with Deightoniella S. Hughes (1952:48) and several pyricularia-like genera. Deightoniella can be easily differentiated from Neocordana since it produces conidiophores reduced to conidiogenous cells with a flattened scar, and conidia with a central pore in the base (Hughes 1952, Klaubauf et al. 2014), while Neocordana has septate conidiophores with denticulate conidiogenous cells and conidia with a protruding hilum. On the other hand, pyricularia-like fungi and Neocordana are similar in having brown, septate conidiophores with polyblastic, denticulate conidiogenous cells. Nevertheless, pyricularia-like fungi are different from Neocordana in having pyriform to obclavate, 2-septate conidia, and grow on grasses and other plants (Seifert et al. 2011, Klaubauf et al. 2014). Neocordana differs by having broadly ellipsoid, obovoid to pyriform, 1-septate conidia and are pathogenic to species of Musa or Canna.

In the phylogenetic analysis generated here (Figure 1), Neocordana is represented by $N$. musae and N. musicola. N. musae is designated as the type species of the genus, and N. musicola is introduced as a new species, similar but different from $N$. musae, based on morphological and molecular data. Unfortunately cultures of $N$. johnstonii and $N$. versicolor were not available to include in the phylogenetic analysis. Nevertheless we propose new combinations for $N$. johnstonii, and $N$. versicolor, based on morphology, pathogenicity and host association. Further studies are needed to confirm their phylogenetic affinities in Neocordana.

\section{Acknowledgements}

We thank the technical staff, Arien van Iperen (cultures), and Mieke Starink-Willemse (DNA isolation, amplification, and sequencing) for their invaluable assistance. 


\section{References}

Arzanlou M., Groenewald J.Z., Fullerton R.A., Abeln E.C.A, Carlier J., Zapater M-F, Buddenhagen I.W., Viljoen A. \& Crous P.W. (2008) Multiple gene genealogies and phenotypic characters differentiate several novel species of Mycosphaerella and related anamorphs on banana. Persoonia 20: 19-37. doi: $10.3767 / 003158508 X 302212$.

Crous P.W., Gams W., Stalpers J.A., Robert V. \& Stegehuis G. (2004) MycoBank: an online initiative to launch mycology into the 21st century. Studies in Mycology 50:19-22.

Crous P.W., Schoch C.L., Hyde K.D., Wood A.R., Gueidan C., de Hoog G.S. \& Groenewald J.Z. (2009a) Phylogenetic lineages in the Capnodiales. Studies in Mycology 64: 17-47. doi: 10.3114/sim.2009.64.02.

Crous P.W., Verkley G.J.M., Groenewald J.Z. \& Samson R.A. (eds). (2009b) Fungal Biodiversity. [CBS Laboratory Manual Series no. 1.] Utrecht: CBS-KNAW Fungal Biodiversity Centre.

Ellis M.B. (1971) Dematiaceous hyphomycetes. X. Mycological Papers 125: 1-30.

de Hoog G.S. (1973) A new species of Cordana (Dematiaceae, Hyphomycetes). Acta Botanica Neerlandica 22: 209-212.

de Hoog G.S., van Oorschot C.A.N. \& Hijwegen T. (1983) Taxonomy of the Dactylaria complex. II. Dissoconium gen. nov. and Cordana Preuss. Proceedings of the Koninklijke Nederlandse Akademie van Wetenschappen, Series C. 86: 197-206.

Hernández-Restrepo M., Gené J., Mena-Portales J., Cano J., Madrid H., Castañeda-Ruiz R.F. \& Guarro J. (2014) New species of Cordana and epitypification of the genus. Mycologia 106: 723-734. doi: 10.3852/13-122.

Hughes S.J. (1952) Fungi from the Gold Coast. I. Mycological Papers 48: 1-91.

Huhndorf S.M., Miller A.N. \& Fernández F.A. (2004) Molecular systematics of the Sordariales: the order and the family Lasiosphaeriaceae redefined. Mycologia 96: 368-387.

Katoh K. \& Standley D.M. (2013) MAFFT multiple sequence alignment software version 7: improvements in performance and usability. Molecular Biology and Evolution 30: 772-80. doi: 10.1093/molbev/mst010.

Jones D.R. (1999) Fungal diseases of the foliage. Cordana leaf spot. pp 99-101. In: Diseases of Banana, Abaca and Enset. Edited by Jones D.R. CABI Publishing. Wallingford, UK. 544 pp.

Nylander J.A.A. (2004) MrModeltest v2.2. Uppsala: distributed by the author. Evolutionary Biology Centre, Uppsala University.

Ploetz R.C., Thomas J.E. \& Slabaugh W.R. (2003) Diseases of Banana and Plantain. In: Diseases of Tropical Fruit Crops. Edited by Ploetz R.C. CABI Publishing. Wallingford, UK. 543 pp.

Preuss C.G.T. (1851) Übersicht untersuchter Pilze, besonders aus der Umgegend von Hoyerswerda. Linnaea 24: 99153.

Priest M.J. (1990) Distribution of Cordana species on Musa in Australia. Mycological Research 94: 861-863.

Rayner R.W. (1970) A mycological colour chart. Kew Commonwealth Mycological Institute.

Réblová M., Barr M.E. \& Samuels G.J. (1999) Chaetosphaeriaceae, a new family for Chaetosphaeria and its relatives. Sydowia 51: 49-70. 
Réblová M. \& Seifert K.A. (2007) A new fungal genus, Teracosphaeria, with a phialophora-like anamorph (Sordariomycetes, Ascomycota). Mycological Research 3: 287-298.

Réblová M. \& Winka K. (2000) Phylogeny of Chaetosphaeria and its anamorphs based on morphological and molecular data. Mycologia 92: 939-954.

Ronquist F., Teslenko M., Mark P. van der, Ayres D.L., Darling A., Höhna S., Larget B., Liu L., Suchard M.A. \& Huelsenbeck J.P. (2012) MrBayes 3.2: efficient Bayesian phylogenetic inference and model choice across a large model space. Systematic Biology 61: 539-542. doi: 10.1093/sysbio/sys029.

Seifert K., Morgan-Jones G., Gams W. \& Kendrick B. (2011). The Genera of Hyphomycetes. [CBS Biodiversity Series 9]. Utrecht: CBS-KNAW Fungal Biodiversity Centre.

Soares D.J., Nechet K.L. \& Barreto R.W. (2005) Cordana versicolor sp. nov. (dematiaceous hyphomycete) causing leaf-spot on Canna denudata (Cannaceae) in Brazil with observations on Cordana musae. Fungal Diversity 18: $147-155$.

Stamatakis A., Hoover P. \& Rougemont J. (2008) A rapid bootstrap algorithm for the RAxML web-servers. Systematic Biology 75: 758-771. doi: 10.1080/10635150802429642.

Tamura K., Stecher G., Peterson D., Filipski A. \& Kumar S. (2013) MEGA6: Molecular evolutionary genetics analysis version 6.0. Molecular Biology and Evolution 30: 2725-2729. doi: 10.1093/molbev/mst197.

Vilgalys R. \& Hester M. (1990) Rapid generic identification and mapping enzymatically amplified ribosomal DNA from several Cryptococcus species. Journal of Bacteriology 172: 4238-4246.

von Höhnel F. (1923) Studien über hyphomyzeten. Centralblatt fur Bakteriologie, Parasitenkunde und Infektionskrankheiten Abteilung. 60: 1-23.

White T.J., Bruns T., Lee J. \& Taylor S.B. (1990) Amplification and direct sequencing of fungal ribosomal RNA genes for phylogenetics. In: PCR Protocols: A Guide to Methods and Applications (Innis M.A., Gelfand D.H., Sninsky J.J., White T.J. eds): 315-322. San Diego: Academic Press.

Zelski S.E., Balto J.A., Do C., Raja H.A., Miller A.N. \& Shearer C.A. (2014) Some dematiaceous freshwater microfungi from Peru and their previously unknown phylogenetic relationships based on 28S nrDNA, and reports of related taxa based on morphology. IMA Fungus 5: 425-438. doi:10.5598/imafungus.2014.05.02.07.

Zimmermann A. (1902) Ueber einige an tropischen kulturepflanzen beobachtete pilze. II. Centralblatt fur Bakteriologie, Parasitenkunde und Infektionskrankheiten II Abteilung. 8: 216-221. 